\title{
Prolonged Inhibition of Vascular Contraction and Calcium Influx by the Novel 1,4-Dihydropyridine Calcium Antagonist Cinaldipine (FRC-8653)
}

\author{
Ryota Yoshimoto, Hideki Dohmoto, Kaoru Yamada' and Atsuo Goto' \\ Life Science Laboratories, Central Research Laboratories, Ajinomoto Co., Inc. \\ 214 Maeda-cho. Totsuka-ku, Yokohama 244, Japan \\ 'Second Deparment of Internal Medicine. Faculty of Medicine, University of Tokyo, \\ 7-3-1 Hongo, Bunkyo-ku, Tokyo 113, Japan \\ Received November 29, 1990 Accepted April 12, 1991
}

\begin{abstract}
We examined the effects of FRC-8653, a novel dihydropyridine calcium antagonist, on the contraction of an arterial preparation and the calcium influx into vascular smooth muscle cells to clarify the long-lasting hypotensive activity of this drug. Inhibition by FRC-8653 persisted for more than $7 \mathrm{hr}$ after its removal, whereas nifedipine and nicardipine exhibited shorter durations of suppressive activity. These results suggest that prolonged inhibition of calcium influx through L-channels contributes to the long-lasting vasodilative and antihypertensive activity of FRC-8653.
\end{abstract}

Calcium antagonists possess potent vasodilative activity, and their therapeutic usefulness in the treatment of essential hypertension and several types of angina pectoris has been wellestablished $(1,2)$. Various compounds with a 1,4-dihydropyridine structure have been developed with the intent of improving the hypotensive activity of nifedipine, the prototype calcium antagonist. FRC-8653 is a new dihydropyridine calcium antagonist synthesized by Fujirebio Inc. (3) that has a strong and longlasting action (4). In accordance with the clinical data, in vitro depolarization experiments using rat arterial preparations have demonstrated that the calcium antagonistic activity of FRC-8653 is longer lasting than those of nifedipine and nicardipine (M. Hosono et al., unpublished data). In the present communication, we examined whether the long-lasting calcium antagonistic activity of FRC-8653 was also seen in rat mesenteric arterial preparations and whether FRC-8653 had a long-lasting inhibitory activity on the calcium influx through cell membranes.

Superior mesenteric arteries from male Splague-Dawley rats $(250-350 \mathrm{~g})$ were cut into helical strips under a binocular microscope. Preparations were mounted in an organ bath and incubated at $37^{\circ} \mathrm{C}$ in oxygenated $\left(95 \% \mathrm{O}_{2}, 5 \% \mathrm{CO}_{2}\right)$ physiological salt solution (PSS) of the following composition: $135 \mathrm{mM}$ $\mathrm{NaCl}, 1 \mathrm{mM} \mathrm{MgCl}, 5 \mathrm{mM} \mathrm{KCl}, 2 \mathrm{mM} \mathrm{CaCl}$, $15 \mathrm{mM} \mathrm{NaHCO}_{3}$, and $1 \mathrm{mM}$ glucose (5). The contraction elicited by raising the $\mathrm{K}^{+}$concentration to $65 \mathrm{mM}$ was isometrically recorded using a force transducer (TB651T, Nihon Kohden, Tokyo, Japan). Tension was initially set at $0.8 \mathrm{~g}$, and the tissues were equilibrated for $1 \mathrm{hr}$, after which they were re-tensioned at $0.8 \mathrm{~g}$. Mesenteric arterial preparations werc initially contracted by $65 \mathrm{mM} \mathrm{KCl}$ as a control response. After removing the high potassium solution, the preparations were treated for $1 \mathrm{hr}$ with one of the following calcium antagonists dissolved in PSS: $1 \times 10^{-9} \mathrm{M}$, FRC$8653,5 \times 10^{9} \mathrm{M}$, nifedipine, $3 \times 10^{-10} \mathrm{M}$ 
nicardipine, and the contractility induced by increasing $\mathrm{KCl}$ concentration to $65 \mathrm{mM}$ was repeatedly examined for $7 \mathrm{hr}$ at 1 -hr intervals. The arterial preparations were washed 3 times after each contraction by $\mathrm{KCl}$.

The inhibitory effect of FRC-8653 on calcium influx was tested in the rat vascular smooth muscle cells (A-10). These cells have been confirmed to express voltage-dependent calcium channels (6). A-10 cells were obtained from The American Type Culture Collection and cultured in Dulbecco's Modified Eagle Medium (DMEM, GIBCO, NY, U.S.A.) supplemented with $10 \%$ fetal bovine serum (FBS) and antibiotics. Assays were carried out on confluent monolayers (4-6 days of subculture in 24-well plates (Corning 25820, NY, U.S.A.)). Studies on net ${ }^{45} \mathrm{Ca}^{2+}$ influx were performed according to the method of Rüegg et al. (7), with a slight modification. Prior to assay, the medium was aspirated and then the subcultured cells were rapidly washed three times with $2 \mathrm{ml}$ of normal balanced salt solution (BSS-n) of the following composition: $145 \mathrm{mM} \mathrm{NaCl}, 5 \mathrm{mM} \mathrm{KCl}, 1 \mathrm{mM} \mathrm{MgCl}_{2}$, $0.1 \mathrm{mM} \mathrm{CaCl}, 10 \mathrm{mM}$ glucosc, and $5 \mathrm{mM}$ HEPES. The incubation for ${ }^{45} \mathrm{Ca}^{2+}$ influx was started by adding $0.5 \mathrm{ml}$ of balanced salt solution for depolarization (BSS-d), which had the following composition: $95 \mathrm{mM} \mathrm{NaCl}, 55 \mathrm{mM}$ $\mathrm{KCl}, 1 \mathrm{mM} \mathrm{MgCl} 2,0.1 \mathrm{mM} \mathrm{CaCl}, 10 \mathrm{mM}$ glucose, $5 \mathrm{mM}$ HEPES and $1 \mu \mathrm{g} / \mathrm{ml}$ of ${ }^{45} \mathrm{CaCl}_{2}$. After $30 \mathrm{~min}$, the reaction was terminated by rapidly aspirating BSS-d and washing the cells three times with ice-cold BSS-n containing $10 \mathrm{mM} \mathrm{LaCl}$ and no calcium. The washed cells dissolved in $1 \mathrm{ml}$ of $0.2 \%$ SDS were transferred into scintillation vials and $7 \mathrm{ml}$ of Triton-toluene scintillation cocktail was added. In the measurements of the duration of inhibitory effect on ${ }^{45} \mathrm{Ca}^{21}$ influx, cells were initially treated with each calcium antagonist at various doses $\left(1 \times 10^{-7} \mathrm{M}, 1 \times 10^{8} \mathrm{M}\right.$ and $1 \times 10^{-9}$ M) for $1 \mathrm{hr}$. The cells were rinsed twice with BSS- $n$ to remove each antagonist at time 0, followed by addition of fresh DMEM with FBS to each well, and incubation was further continued at $37^{\circ} \mathrm{C}$. The cells were washed twice with BSS-n at $2 \mathrm{hr}$ intervals, and the ${ }^{45} \mathrm{Ca}^{2+}$ influx was assayed every $2 \mathrm{hr}$ until $8 \mathrm{hr}$ after removal of the drug.

FRC-8653 was synthesized as the racemic compound at the Central Rescarch Laboratories, Ajinomoto Co., Kanagawa, Japan. Nifedipine and nicardipine were obtained from Sigma Chemical Co., MO, U.S.A. ${ }^{45} \mathrm{CaCl}_{2}$ was obtained from New England Nuclear, MA, U.S.A.

The recovery of contractility of rat superior mesenteric arteries suppressed by various calcium antagonists was determined. As shown in Fig. 1, the arterial preparation treated with nifedipine recovered complete contractility $2 \mathrm{hr}$ after drug removal. Inhibition causcd by nicardipine was slowly restored and about $50 \%$ suppression remained at $7 \mathrm{hr}$ after removal of the drug. In the preparation treated with FRC-8653, inhibition persisted throughout the experimental period and approximately $70 \%$ suppression was still observed $7 \mathrm{hr}$ after removal of the drug. Several laboratories have studied the long acting effects of dihydropyridine calcium antagonists $(8-10)$. In these studics, calcium antagonistic agents were evaluated according to the duration of their inhibitory effect on the contractile responses of vascular preparations to depolarizing stimu-

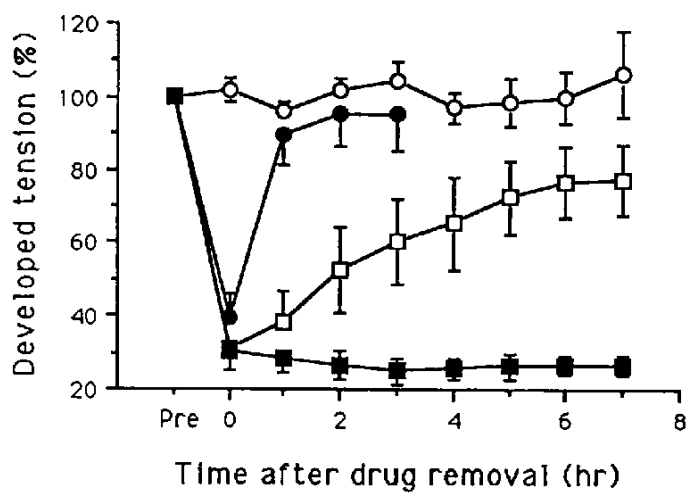

Fig. 1. Duration of the inhibitory effect of FRC-8653 $\left(1 \times 10^{-9} \mathrm{M}\right)$, nifedipine $\left(5 \times 10^{-9} \mathrm{M}\right)$, nicardipine $\left(3 \times 10^{-10} \mathrm{M}\right)$ on contractions of rat mesenteric arteries evoked by $65 \mathrm{mM} \mathrm{KCl}$ : control (O), FRC-8653 ( $\square$ ), nifedipine (O), nicardipine $(\square)$. Each point represents the mean $\pm S$.E. of 4 experiments. 
li. Using a similar method, we examined the duration of the calcium antagonistic activity of FRC-8653 and confirmed that its inhibitory effect was markedly sustained as compared with those of nifedipine and nicardipine. We therefore suppose that the long-lasting hypotensive activity of FRC- 8653 would be at least partly mediated by the prolonged calcium antagonistic property associated with this drug.

As sources of increased intracellular calcium, two major mechanisms have become evident. One is the influx of extracellular calcium ions through the cell membrane and the other is the release from the intracellular calcium store (11). Many studies support the view that the vasodilative and calcium antagonistic activities of dihydropyridine calcium antagonists result from blocking the calcium influx through L-channels $(8,12)$. Although movement of calcium ions through L-channels has not been directly measured in the previous studies, continuous suppression of vascular contraction brought about by long-lasting calcium antagonists is generally assumed to result from prolonged suppression of L-channels. To clarify the mechanism of the continuous vasodilative activity of long-lasting calcium antagonists, calcium influx into vascular smooth muscle cells needs to be directly measured. We therefore tested FRC-8653 for its inhibitory effect on calcium influx using a rat aortic smooth muscle cell line that has L-type calcium channels (6). In BSS- $n,{ }^{45} \mathrm{Ca}^{2+}$ influx was $1353 \pm 56 \mathrm{cpm} /$ well, and it increased to $2486 \pm 46 \mathrm{cpm} /$ well in high $\mathrm{K}^{+}$solution (BSSd). In the presence of nifedipine $\left(1 \times 10^{-7}\right.$ $M)$, the influx was suppressed to $851 \pm 35$ $\mathrm{cpm} /$ well, lower than that in BSS-n. These are the same results as previous reports that suggest partially depolarized membrane potential and the partially activated state of L-type calcium channels $(6,7)$ of vascular smooth muscle cells in culture. As shown in Fig. 2, dihydropyridine calcium antagonists inhibited the depolarization-induced increase in ${ }^{45} \mathrm{Ca}^{2+}$ influx into A10 cells. In the kinetic analysis, partial recovery of ${ }^{45} \mathrm{Ca}^{2+}$ influx was observed
FRC-8653
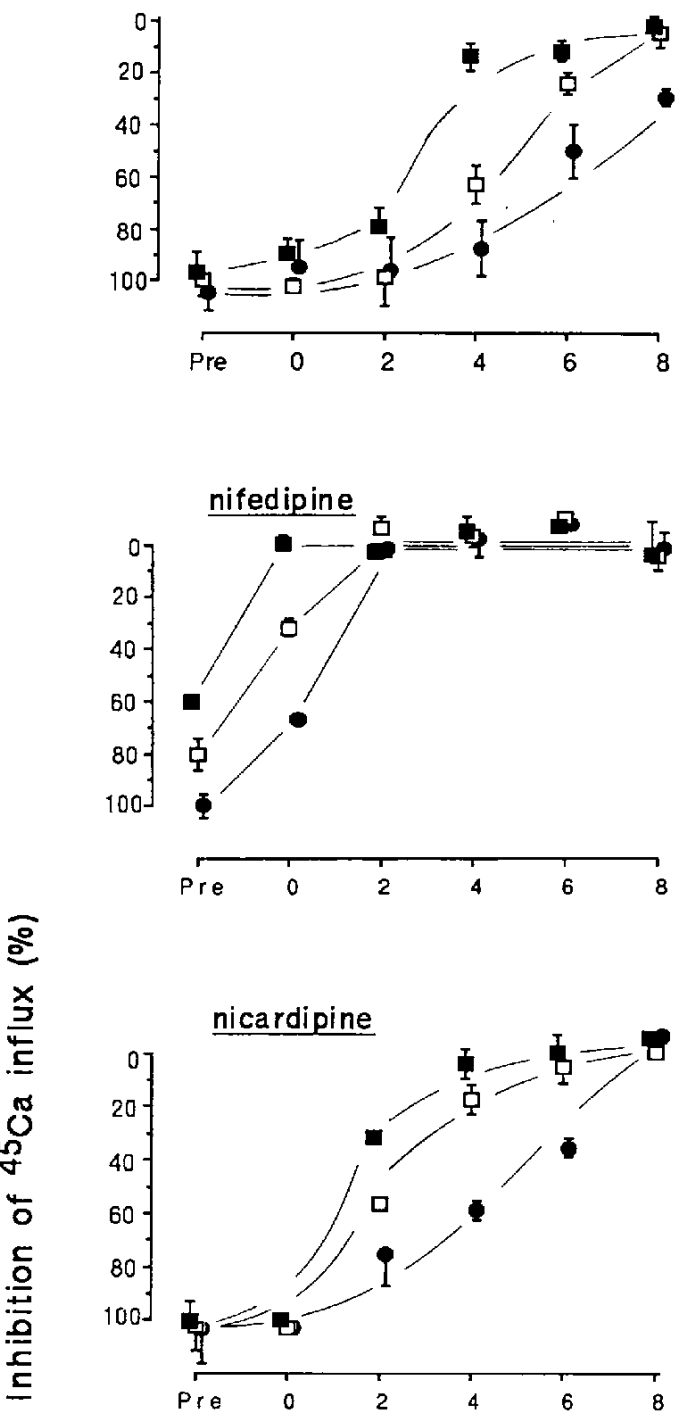

\section{Time after drug removal ( $h r$ )}

Fig. 2. Duration of the inhibitory effect of various concentrations $\left(O, 1 \times 10^{-7} \mathrm{M} ; \Pi, 1 \times 10^{8} \mathrm{M}\right.$; $\left.\square, 1 \times 10^{-9} \mathrm{M}\right)$ of FRC-8653, nifedipine and nicardipine on the net ${ }^{45} \mathrm{Ca}^{2+}$ influx of $\mathrm{A}-10$ cells evoked by $55 \mathrm{mM} \mathrm{KCl}$; Each point represents the mean \pm S.E. of 4 wells. $10 \%$ inhibition represents the value obtained with BSS-d alone. and $100 \%$ inhibition is the value obtained at maximal inhibition as defined with $10^{-7} \mathrm{M}$ nifedipine in BSS-d. Inhibition of ${ }^{45} \mathrm{Ca}^{2+}$ influx in the presence of each calcium antagonist was also measured and expressed as pre-wash values (Pro). 
at time 0 in nifedipine treated A 10 cells at cach drug concentration, suggesting that there was a partial dissociation of nifedipine molecules from their receptors caused by rinsing with BSS-n before the ${ }^{45} \mathrm{Ca}^{2+}$ load. After $2 \mathrm{hr}$, influx restored to the control level at each drug concentration. It took 4 to $8 \mathrm{hr}$ for the influx of the nicardipine-treated cells to return to the conrol level. The restoration of ${ }^{45} \mathrm{Ca}^{2+}$ influx was the slowest in the cells treated with FRC-8653 and about $30 \%$ inhibition still persisted even after $8 \mathrm{hr}$ at the concentration of $1 \times 10^{-7} \mathrm{M}$.

Inhibition by each calcium antagonist in the depolarized mesenteric arterial preparations lasted longer than that in the ${ }^{45} \mathrm{Ca}^{2+}$ influx assay. One reason for this may be that the influx experiment enables the clearance of calcium antagonists from cell surfaces because of the coexisting serum proteins in the culture medium. Serum albumin is generally known as the major carrier protein of dihydropyridine calcium antagonists in the blood (13). In fact, when the depolarization experiment was performed by rinsing the arterial preparations with PSS which that contained bovine serum albumin, FRC-8653 treated preparations recovered contractility quickly so that only $25 \%$ inhibition was ovserved after $4 \mathrm{hr}$ (data not shown). The other possibility that there maybe a metabolic turn over or internalization of dihydropyridine receptors from the cell membrane. It is known that there is a turnover of membrane receptors within hours on cultured cell surfaces and that the membranc receptors are internalized into the cytoplasm when ligands bind to them. Therefore the possibility cannot be excluded that there is a turnover of dihydropyridine receptors inactivated by FRC8653 and/or other calcium antagonists, and new active receptors appear on the cell membrane.

Oike et al. have observed that racemic FRC-8653 produce both excitatory and inhibitory effects on the depolarization pulse induced $\mathrm{Ba}^{2+}$ current in the rabbit basilar artery (14). The $(+)$ enantiomer mainly has excitatory and $(-)$ enantiomer inhibitory actions at the holding potential of $-80 \mathrm{mV}$. When the holding potential is increased to $-40 \mathrm{mV}$, both enantiomers have an inhibitory action. In the present study, racemic FRC-8653 was utilized and not excitatory but inhibitory action was observed on the depolarization induced ${ }^{45} \mathrm{Ca}^{2+}$ influx in A10 cells. This result can be explained by two different assumptions. One possibility is that both the $(+)$ and $(-)$ enantiomers have inhibitory action under the present experimental conditions. The fact that the A10 cells have partially depolarized membrane potential in culture (15) may support this hypothesis because both enantiomers have inhibitory action at the potential of $-40 \mathrm{mV}$ in the rabbit basilar artery. The other is that the (-) enantiomer produces an inhibitory action and the $(+)$ enantiomer produces an excitatory action, but it is weaker than the inhibitory action of the (-) enantiomer, on the $\mathrm{Ca}^{2+}$ influx in $\mathrm{Al0}$ cclls. In this case, racemic FRC-8653 is thought to have a net inhibitory action, as the sum of the contrary actions of the $(+)$ and $(-)$ cnantiomers.

The in vitro monitoring of tension in the vascular preparation can be used to evaluate mechanical force and its suppression by calcium antagonists. The long-lasting inhibitory effect of calcium antagonists on vascular contraction is generally assumed to result from long-lasting inhibition of L-channels $(8-10)$, but the direct measurement of calcium influx through L-channels has not been attempted in previous studies. In the present study, we examined directly the influx of calcium ions through the cell membrane and confirmed that FRC-8653 inhibited calcium influx for a longer time than nifedipine and nicardipine. This result indicates that the long lasting hypotensive and vasodilative activity elicited by FRC- 8653 may be maintained by continuous inhibition of calcium influx from the extracellular fluid into vascular smooth muscle cells. Whether this inhibition may be mediated through continuous binding of FRC-8653 to dihydropyridine receptors on the vascular smooth muscle remains to be determined. 


\section{Acknowledgments}

The authors are grateful to Dr. Y. Irie and Dr. N. Yasuda for kindly supplying us with the FRC-8653 used in this investigation.

\section{REFERENCES}

1 Fleckenstein, A.: History of calcium antagonists. Circ. Res. 52, Supp. I, 3-16 (1983)

2 Bühler, F.R.: Calcium antagonists. In Hypertension (Pathophysiology, Diagnosis and Management), Edited by Laragh, J.H. and Brenner, B.M., Vol. 2, p. 2169-2179, Raven Press Ltd., New York (1990)

3 Iida, H., Fujiyoshi, H., Ikeda, K., Hosono, M. Yamamura, T., Kase, N., Sekine, A. and Uematsu, T.: Antihypertensive and cardiovascular effects of a new dihydropyridine derivative, 2methoxycthyl(E)-3-phenyl-2-propen-1-yl-1,4-dihydro2,6-dimethyl-4-(3-nitrophenyl)pyridine-3,5-dicarboxylate (FRC-8653). Japan. J. Pharmacol, 43, Supp. 296P (1987)

4 Ishii, M., Matsuoka, H., Yoshida, K., Higuma, K., Shindo, Y., Tsukiyama, H., Tohyama, S., Yoshii, U., Usui, T., Sekine, S., Takagi, N., Nishiyama, K., Ikeda, T. and Joki, E.: A preliminary study on the antihypertensive property of FRC-8653, a new long-acting calcium antagonist, in essential hypertension. Cardiovasc. Drugs Ther. 3, Supp. 2, 595 (1989)

5 Kasuya, Y., Masuda, Y. and Shigenobu, K.: Possible role of endothelium in the vasodilator response of rat thoracic aorta to platelet activating factor (PAF). J. Pharmacobiodyn. 7, 138-142 (1984)

6 Kongsamut, S., Freedman, S.B. and Miller, R.J.: Dihydropyridine sensitive calcium channels in a smooth muscle cell line. Biochem. Biophys. Res. Commun. 127, 71-79 (1985)

7 Rüegg, U.T., Doyle, V.M., Zuber, J.-F. and Hof, R.P.: A smooth muscle cell line suitable for the study of voltage sensitive calcium channels. Biochem. Biophys. Res. Commun. 130, 447-453 (1985)

8 Shibouta, Y., Kitayoshi, T., Kitoh, G. and Nishikawa, K.: Calcium channel blocking action of franidipine hydrochloride (CV-4093.2HCl) in vitro and in vivo. Japan. J. Pharmacol. 48, 463-472 (1988)

9 Burges, R.A., Gardiner, D.G., Gwilt, M., Higgins, A.J. and Stubbs, J.K.: Calcium channel blocking properties of amlodipine in vascular smooth muscle and cardiac muscle in vitro: Evidence for voltage modulation of vascular dihydropyridine receptors. J. Cardiovasc. Pharmacol. 9. $110-119(1987)$

10 Furuta, T.: Prolonged inhibitory effects of nilvadipine (FR34235) following washout in isolated rabbit aorta and mesenteric artery. J. Cardiovasc. Pharmacol. 11, 134-138 (1988)

11 Somlyo, A.P. and Somlyo, A.V.: Vascular smooth muscle: Calcium, magnesium and vascular smoothmuscle function. In Hypertension (2nd ed), Edited by Genest, J., Kuchel, O., Hamet, P. and Cantin, M., p. 441-457, McGraw-Hill Book Co., New York (1983)

12 Terai, M., Takenaka, T. and Maeno, H.: Inhibition of calcium influx in rabbit aorta by nicardipine hydrochloride (YC-93). Biochem. Pharmacol. 30, 375-378 (1981)

13 Krause, H.P., Ahr, H.-J., Beermann, D., Siefert, H.M., Suwelack, D. and Weber, H.: The pharmacokinetics of nitrendipine. Arzneimitteforschung 38, 1593 - 1598 (1988)

14 Oike, M., Inoue, Y., Kitamura, K. and Kuriyama, $\mathrm{H}$.: Dual action of FRC8653, a novel dihydropyridine derivative, on the $\mathrm{Ba}^{2+}$ current recorded from the rabbit basilar artery. Circ. Res. 67, 9931006 (1990)

15 Kimes, B.W. and Brandt, B.L.: Characterization of two putative smooth muscle cell lines from rat thoracic aorta. Exp. Cell Res. 98, 349-366 (1976) 